\title{
Examination under anaesthesia of the rectum for removal of gallstones
}

\author{
Michael F Bath, Rhys George, Zakir J Hussain, Niall O Aston
}

Department of Surgery, Queen Elizabeth Hospital, London, UK

\section{Correspondence to}

Dr Michael F Bath, michael.bath@doctors.org.uk

Accepted 11 January 2019

\section{DESCRIPTION}

An 81-year-old woman presented following 2 days of upper abdominal pain, vomiting and absolute constipation. Her abdomen was distended and there was tenderness in the epigastrium. She was known to have gallstones, however had not had any previous abdominal surgery.

A computerised tomography (CT) scan of the abdomen and pelvis showed dilated small bowel loops with an impacted gallstone in the distal ileum (figure 1) with collapsed bowel distal to this point. A cholecystoduodenal fistula was also noted, in addition to a thickened and inflamed gallbladder.

She had a laparotomy the following day. No obstructing intraluminal mass was identified intraoperatively and no enterotomy was performed. Postoperatively, her clinical picture improved with conservative management, however the patient did report a fullness in her rectum.

A repeat CT scan 10 days after her laparotomy showed two large obstructing stones in the rectum (figure 2), both having spontaneously passed through the ileocaecal valve. Despite regular laxatives and repeated enemas, only one of the gallstones passed spontaneously. She remained symptomatic and had an examination under anaesthesia of the rectum and flexible sigmoidoscopy 23 days into her

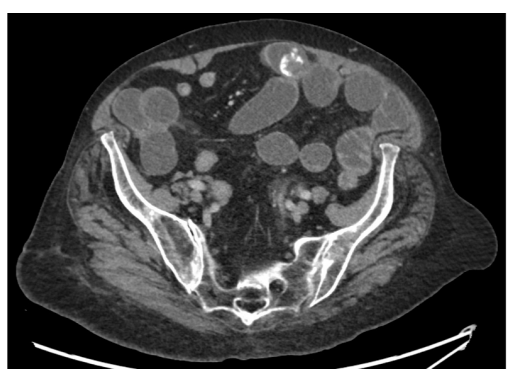

Figure 1 Axial CT image demonstrating the enteric gallstone positioned in the distal ileum at presentation.

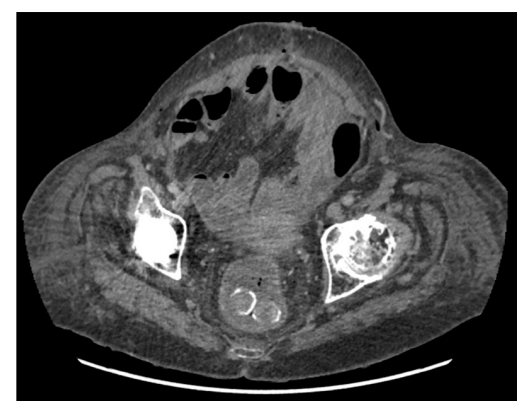

Figure 2 Axial $\mathrm{CT}$ image demonstrating the two enteric gallstones positioned in the rectum, prior to the examination under anaesthesia.

admission. A gallstone measuring $4 \mathrm{~cm}$ was successfully extracted from the rectum.

\section{Learning points}

Gallstone ileus is a rare complication of cholecystitis, and a conservative approach may be a suitable initial management option in certain cases, even with large obstructing stones.

- For symptomatic gallstones that have passed spontaneously into the colon, endoscopic retrieval may provide an alternative lessinvasive retrieval option.

Contributors MB co-wrote and reviewed the article, and obtained the images. RG and ZJH co-wrote the article. NA reviewed the article.

Funding The authors have not declared a specific grant for this research from any funding agency in the public, commercial or not-for-profit sectors,

Competing interests None declared.

Patient consent Obtained.

Provenance and peer review Not commissioned; externally peer reviewed.

Copyright 2019 BMJ Publishing Group. All rights reserved. For permission to reuse any of this content visit

https://www.bmj.com/company/products-services/rights-and-licensing/permissions/

BMJ Case Report Fellows may re-use this article for personal use and teaching without any further permission.

Become a Fellow of BMJ Case Reports today and you can:

- Submit as many cases as you like

- Enjoy fast sympathetic peer review and rapid publication of accepted articles

- Access all the published articles

- Re-use any of the published material for personal use and teaching without further permission

For information on Institutional Fellowships contact consortiasales@bmjgroup.com

Visit casereports.bmj.com for more articles like this and to become a Fellow 